\title{
Implementation and Evaluation of Effectiveness of Educating Program for Upgrading Nurses' Knowledge Regarding Polycystic Ovaries Syndrome
}

\author{
Hadayat A. Amasha, Manar F. Heeba \\ Department of Obstetric \& Gynecological Nursing, Faculty of Nursing, Port Said University, Egypt
}

\begin{abstract}
Polycystic ovarian syndrome (PCOS) is the most common endocrine disease of women of reproductive age, yet it remains undiagnosed for many women. The reason the syndrome is often not diagnosed or is misdiagnosed is because PCOS can present with a variety of abnormalities that can be present in other endocrine dysfunctions. With appropriate diagnosis and management, the patient may delay or prevent negative physical and psychological consequences brought on by this syndrome. Maternity nurses can serve a vital role in this process, improving screening rates, referral and patient education. The aim of this study was to implementation and evaluation of effectiveness of educating program for upgrading nurses' knowledge regarding PCOS at maternity clinics of all medical health centers in Port Said City. Design: a quasiexperimental one-group pre test/ posttest design was adopted for the study. The sample included 50 nurses working in those clinics. Tool: A semi-structured questionnaire was used to assess nurses' socio-demographic data and their knowledge regarding polycystic ovarian syndrome. Results: The result showed that the nurses lack of knowledge about PCOS and there is a statistically significant difference in the mean of pre test and posttest scores $(P=<0.001)$. There was no significant association between level of knowledge and sociodemographic variables. Conclusion: This study reflects the need for staff development program to increase maternity nurses' level of knowledge related to PCOS.
\end{abstract}

Key words: Educational program, PCOS, knowledge, maternity nurses

\section{Introduction}

Polycystic ovary syndrome (PCOS) is a complex heterogeneous endocrine disorder. It is a common disorder affecting $4-12 \%$ of women of reproductive age ${ }^{(1,2)}$. PCOS was first described in the United States in $1935^{(3)}$, and it is characterized by chronic anovulation and hyperandrogenism in the absence of underlying adrenal or pituitary disease ${ }^{(4)}$. PCOS is also reported to be associated with obesity, insulin resistance and type II diabetes, dyslipidemia, hypertension, cardiovascular disease and endometrial carcinoma ${ }^{(5,6,7)}$.

In October 2013, the Endocrine Society released practice guidelines for the diagnosis and treatment of PCOS ${ }^{(8)}$. Treatment of PCOS must focus both on normalizing short-term signs of hyperandrogenism and an ovulation and on reducing metabolic complications. This can be achieved through pharmacological intervention or preferably lifestyle modification ${ }^{(9)}$. Lifestyle modifications are considered first-line treatment for women with PCOS ${ }^{(10)}$. Weight loss is an important treatment strategy; it improves practically every parameter of PCOS where weight loss restores ovulation and pregnancy rates, decreases insulin levels, lowers testosterone levels while raising sex hormone binding globulin (SHBG) levels.

Maternity health nurses hold a critical role in modern health care that goes beyond their day-to-day duties. They share more information with patients than any other provider group, offering understanding of complex health issues, holistic approaches to ailments, and advice for the patient that extends to the family ${ }^{(11}$, 12). The aim of this study was conducted to implementation and evaluation of effectiveness of educating program for upgrading nurses' knowledge regarding PCOS at maternity clinics of all medical health centers in Port Said City.

\section{Research hypothesis}

$\mathrm{H}_{1:}$ The mean knowledge score of maternity nurses about PCOS posttest will be higher than pre test.

$\mathrm{H}_{2}$ : There will be no significant association between the posttest knowledge score and demographic variables of maternity nurses. 


\section{Research design and sampling}

\section{Material and methods}

A quasi-experimental - one group pretest/posttest research design was utilized in this study. All nurses (50) working at the maternity clinics of medical health centers in Port Said City, Egypt were included. Port Said City located on the Mediterranean Sea and the Suez Canal passes through it.

\section{Research setting}

The study was conducted at all medical health centers in Port Said city, the total number was 15 medical health centers. In collaboration with Canal cities and Sinai Nursing Syndicate in Port Said City, the researchers conducted a program sessions in the period from 1-15 October 2013 in the Conference Hall of AlAmery Hospital, (the largest and oldest Ministry of Health Hospital in Port Said City).

\section{Target Population}

The target populations of this study were female nurses working at the maternity health clinics in all medical heath centers in Port Said City for no less than 2 years.

\section{Tools of data collection}

Based on the related literature; a semi-structured questionnaire was developed (Arabic language) by the researchers for the purpose of the current study. The Questionnaire included the following:

1- Nurses socio-demographic characteristics such as age, nursing qualifications, marital status, family income, experience years, attended training program before in the field of work.

2- Nurses' knowledge about polycystic ovary syndrome (definition- causes- risk factors, signs and symptoms, complications, diagnostic criteria, goals of management, the treatment strategies and nursing role).

A jury from experts in the nursing field tested the content validity; minor necessary modifications were done mainly in the form of rephrasing some sentences and changing some items.

\section{Scoring system}

For the knowledge items, a correct response was scored one and the incorrect Zero. For each area of knowledge, the scores of the items were summed-up and the total divided by the number of the items, giving a mean score for each area. Maximum available score is $60(100 \%)$ and least is zero $(0.00 \%)$. These scores were converted into a percent score. Whereas poor knowledge scored $<30$ grades $(<50 \%)$; average knowledge scored $30-<39(50-<65 \%)$; knowledge was considered good if the percent score was $65 \%$ or more $(39-60$ grades).

\section{Intervention and evaluation of program}

The participants scheduled their availability for the intervention program and then were divided into two equal groups, each group contains 25 nurses. Informed consent and socio-demographic sheet were obtained from those willing to participate in the study through Canal Cities and Sinai Nursing Syndicate in Port Said City.

The program was implemented for successive two weeks ( 2 days/ week). A pre test was conducted as a first level of intervention; then, 6-hrs interactive lectures were used, intervention started from 9.30 a.m and power point presentation was done, followed by a group discussion entitled, "overview of PCOS". The content included information about anatomy and physiology of female reproductive system, definition of PCOS, signs and symptoms, and causes as well as the risk factors of PCOS.

At the next days, other session a seminar that provided conceptual information regarding PCOS prevention, treatment and nursing role, presented by the second author (Heeba M.F.), and at the end of every session participants' questions were discussed. In the second level of intervention, multimedia resources were given to or made available to the participants. The resources included the following: Printed seminar handouts; and an illustrated, colored booklet of PCOS, which was prepared by the authors.

At the end of the education program, knowledge of nurses were assessed (post test) using the same pretest tool.

\section{Ethical and administrative considerations}

Prior to seeking the consent of nurses to participate in the research, it was essential to gain the support of Canal cities and Sinai nursing syndicate in Port Said city and managers' trust. All official permissions to carry out the study were secured from pertinent authorities. An informed oral consent was obtained from all the participants before collecting data. Explanation of the study aim in a simple manner was done. All data were considered confidential. Participants were informed about their right to withdraw from the study at any time without giving any reason. 
At the beginning of the lecture/ seminar, to ensure anonymity, names and personal identification were not used in any part of the study. The participants asked to select a number or symbol and use it on the pre-/ posttests. The pre-and post tests then was linked via the number or symbol for comparison.

\section{Statistical analysis of the data}

Data were fed to an IBM computer and analyzed using the statistical Package for the Social Sciences (SPSS), version 20.0. Qualitative data were described using number and percent. Quantitative data were described using mean and standard deviation, range. Comparison between different groups regarding categorical variables was tested using Chi-square test. When more than $20 \%$ of the cells have expected count less than 5 , correction for chi-square was conducted using Monte Carlo correction. For normally distributed data, comparison between different groups were analyzed using F-test (ANOVA), also paired t-test is used to analyze two paired data. Correlations between two quantitative variables were assessed using Pearson coefficient. Significance test results are quoted as two-tailed probabilities. Significance of the obtained results was judged at the $5 \%$ level $^{(13,14)}$.

\section{Results}

Table (1) shows the distribution of the studied nurses according to their socio-demographic characteristics. In relation to age, $16.0 \%$ were in the age group 50 years or more. The mean age was $39.12 \pm$ 10.15 years and ranged from $25-58$ years.

Concerning their qualification, the majority of studied nurses $(86.0 \%)$ has nursing diploma, only three nurses $(6 \%)$ completed the bachelor degree. Seventy two percent of the sample had years of experience 5 years or more in maternity clinics.

In relation to marital status, $88.0 \%$ of studied sample were married, only $10 \%$ were single and $46 \%$ of them had $\leq 1000$ LE monthly family income. The same table indicates, 10 nurses $(20 \%)$ of the studied sample reported that they had previous history of PCOS, while $80 \%$ of the total sample mentioned that they had no family history and $18.0 \%$ of them reported that they have been involved in the management of PCOS cases through their work.

Considering previous PCOS courses attended, the vast majority $(96.0 \%)$ did not attend any training courses, and $80.0 \%$ of them reported they did not have any knowledge regarding PCOS. On the other hand, only three nurses $(6 \%)$ identified media as their source of information. As regards nurses' opinion about community awareness, $70 \%$ of them stated that community needed to increase their awareness about PCOS, (table 1).

Table (2) shows that only $2 \%$ of the nurses had average knowledge related to PCOS before the implementation of the program. However, it was $34.0 \%$ after implementation of the program. The vast majority $(98.0 \%)$ of the nurses had poor knowledge related to overall PCOS before the implementation of the program, while after implementation of the program, $46.0 \%$ of them had good level of knowledge.

The same table shows minimum, maximum, mean and standard deviation of pre and posttest knowledge score of PCOS. This recognizes higher knowledge scores, min. (21), max. (48) And mean $(36.46 \pm 6.51)$ in posttest when compared to their pretest knowledge scores, min. (0.0), max. (33), mean (8.02 \pm $7.29)$, and the difference between pre and post test score was statistically significant $(\mathrm{t}=19.174$ at $\mathrm{p}=<0.001)$.

Concerning nurses' knowledge about meaning, causes, risk factors, signs and symptoms, complications, diagnosis, objective of treatment, management and nursing care regarding PCOS, table (3) shows area wise mean knowledge score, mean difference standard deviation and ' $t$ ' value of the pre and posttest. Statistically significant differences between the pre test and posttest level of knowledge about PCOS after the program implementation were observed. The highest fulfilled knowledge was observed in diagnosis, meaning (definition), risk factors and causes $(86.67,86.0,85.0,80.0)$ respectively. Statistically significant differences were detected between pre and post program in all items $(\mathrm{p}=<0.001)$.

Table (4) shows relationship between nurses' knowledge score about PCOS and their general characteristics. More than two fifths (43.5\%) of the study subjects who gained good score of knowledge aged 30 $-<40$ years compared to $8.7 \%$ of those aged 50 years or more. It is also observed that $100.0 \%$ and $73.9 \%$ of the nurses who exhibit good knowledge regarding PCOS have duration of experience equal or more than 5 years in general nursing and in maternity clinics respectively. No statistically significant different relations were revealed between knowledge about PCOS and their socio-demographic characteristics.

\section{Discussion}

Lack of knowledge toward PCOS among girls and not taking any measures to improve their lifestyle patterns that they can be helped by assessing their knowledge and views to change lifestyle by providing necessary information, so as to help them to get aware about the polycystic ovarian syndrome ${ }^{(15)}$.

Nurses play an important and effective role in the education of the population. Several authors point to that the maternity nurse plays a pivotal role in educating and empowering women with PCOS. As well, nurses 
should be knowledgeable and highly skillful in providing nursing care according to women's needs and problems to save their lives, therefore, this study was conducted to implementation and evaluation of effectiveness of educating program for upgrading nurses' knowledge regarding PCOS at maternity clinics of all medical health centers in Port Said City. The findings of the present study showed that the vast majority of studied nurses had never attend any formal training program about PCOS and the majority of them did not have any information. In other studies conducted by many authors, they found similar results $(16,17,18)$.

Lack of knowledge regarding PCOS may be due to the fact that, maternity nurses in port Said City did not receive the needed information or may be in need for refreshment in-service training program. On the other hand, they are facing many difficulties in the area of women care, because most of health care settings are lacking standardized care guidelines.

Findings of the present study showed highly statistically significant improvement in nurses' knowledge immediately after program implementation, as significant differences were found between the mean pre test and post test knowledge score. The post test mean percentage $(60.77 \pm 10.85)$ was found to be higher than the pretest mean percentage $(13.37 \pm 12.14)$ scores regarding PCOS. This finding is consistent with that of a study conducted by Rodzik (2008) ${ }^{(19)}$; in which the total osteoporosis self-efficacy scale score increased from pretest to posttest and the change was statistically significant. As well, the significant improvement of the maternity nurses' knowledge after attending the program in the present study is congruent with Abd El-Halem (2012) ${ }^{(17)}$ who mentioned that the educational program was effective in improving nurses' knowledge and performance related to pregnancy induced hypertension.

The present study reflected area wise pre and posttest knowledge mean score of studied nurses. It showed that the highest improvement of knowledge regarding all the program content and mean posttest score was higher than the mean pretest knowledge score. The mean differences were statistically significant $(\mathrm{P}=$ $<0.05)$. This indicates the significant effectiveness of the PCOS program in increasing the level of knowledge of maternity nurses. These results were supported by those of a study conducted by Sowmya and Philomena (2013) ${ }^{(15)}$ regarding effectiveness of PCOS structured teaching program on 80 adolescent girls in a selected college at Mangolore. In addition, Wassef (1998) ${ }^{(20)}$ and Akel (1997) ${ }^{(21)}$, who stated that the high improvement of the program on subject's knowledge was expected after implementation of the program, which support the current study finding.

Findings of the present study revealed that there is no statistically significant relation between nurses' knowledge and nurses' age, years of experience, and family income. Some of these findings are incongruent with Mackenzie and Buchan (1998) ${ }^{(22)}$, who mentioned that longer nursing experience indicated better nursing background, which paves the way for interacting with knowledge. In addition, these results are contrasted with Abd Rabo (1997) ${ }^{(23)}$, who mentioned that younger nurses were more motivated to achieve technical skills and acquire knowledge than more experienced nurses which is logic where the younger the age of the learner, the more capability of accepting new knowledge.

\section{Conclusions}

Polycystic ovarian syndrome that can lead to several health related problems and affects women health if not managed properly. Staff development program through continuous education and training on PCOS helps them to gain updated knowledge, hence helps to early detection and prevent related complications of PCOS. The present study was conducted to implementation and evaluation of effectiveness of educating program for upgrading nurses' knowledge regarding PCOS at maternity clinics of all medical health centers in Port Said City. The finding of the study revealed that maternity nurses lack knowledge regarding PCOS program and there are no statistically significant differences between mean score change of nurses' knowledge in relation to qualification, years of experience, marital status as well as monthly family income. The mean knowledge score improved immediately after implementation of the program. Therefore, the study concluded that implementing an education program is effective in increasing the level of knowledge of maternity nurses regarding PCOS.

\section{Recommendations}

Based upon the findings of the study, the following recommendations can be deduced.

- Nursing school curriculum should be updated to include more information about PCOS.

- Continuous in-service educational programs for maternity nurses to be conducted at different levels in order to improve health care delivery.

\section{References}

[1]. Sheehan, M.T.(2004). Polycystic ovarian syndrome: Diagnosis and management. Clin Med Res, 2, 13-27.

[2]. Azziz. R., Woods, K.S., Reyna, R., Key, T.J., Knochenhauer, E.S, \& Yildiz, B.O.( Jun 2004). The prevalence and features of the polycystic ovary syndrome in an unselected population. J Clin Endocrinol Metab, 89(6), 2745-9.[Medline]. [Full Text].

[3]. Stein, I.F., Leventhal, N.L. (1935). Amenorrhea associated with bilateral polycystic ovaries. Am J Obstet Gynecol, 29, 181-91.

[4]. Ehrmann, D.A. (2005). Medical Progress: Polycystic Ovary Syndrome. N Engl J Med, 2005;352:1223-36. 
[5]. Carmina, E., Lobo, R.A. (1999). Polycystic ovary syndrome (PCOS). Arguably the most common endocrinopathy is associated with significant morbidity in women. J Clin Endocrinol Metab, 84, 1897-9.

[6]. Dahlgren, E., Janson, P.O., Johansson, S. (1992). Polycystic ovary syndrome and risk for myocardial infarction. Evaluated from a risk factor model based on a prospective population study of women. Acta Obstet Gynecol Scandinav, 71, 599-604.

[7]. Dunaif, A, Segal, K.R., Futterweit, W. (1989). Profound peripheral insulin resistance, independent of obesity, in polycystic ovary syndrome. Diabete, 38, 1165-74.

[8]. [Guideline] Legro, R.S., Arslanian S.A., Ehrmann, D.A. Diagnosis and treatment of polycystic ovary syndrome: An Endocrine society clinical practice guideline. J Clin Endocrinol Metab. Retrieved Oct 22 2013;[Medline].

[9]. Norman, R., Davies, M., Lord, J.(2002). The role of lifestyle modification in polycystic ovary syndrome. TRENDS Endocrinol Metab, 13, 251-7.

[10]. Vause, T.D., Cheung, A.P., Sierra, S., Claman, P., Graham, J., Guillemin, J.A. ( 2010). Ovulation induction in polycystic ovary syndrome. J Obstet Gynaecol Can, May, 32(5), 495-502. [Medline].

[11]. Sherif, K. (2006). Polycystic ovary syndrome in primary care. Female Patient, 31(1), 25-29.

[12]. Palmer, R.C., \& Midgette, L.A. (2008). Preventive health patient education and counseling: A role for medical assistants. Journal of Allied Health, 37(3), 137-43.

[13]. Leslie, E., Geoffrey, J. \& James, M.(eds). (1991). Statistical analysis. In: Interpretation and uses of medical statistics $\left(4^{\text {th }}\right.$ ed). Oxford: Scientific Publications. pp. 411-6.

[14]. Kirkpatrick, L.A., Feeney, B.C. (2013). A simple guide to IBM SPSS statistics for version 20.0. Student ed. Belmont, Calif.: Wadsworth, Cengage Learning. p. 115.

[15]. Sowmya, A.M., Philomena, F. (2013). Effectiveness of structured teaching of polycystic syndrome among adolescent girls. Nitte university Journal of Health Science, 3(3), 54-58.

[16]. Varghese, N.M, Kumari, V. \& Madanla, M. (2013). Evaluation of effectiveness of an informational booklet on prevention of osteoporosis in terms of knowledge, attitude and expressed practices of working women. IOSR-JNHS, 2(5), 10- 18.

[17]. Abd El-Halem, El-S. H. (2013). Educational programme for nurses about pregnancy induced hypertension in Port Said (Unpublished Ph.D dissertation). University of Port Said, Faculty of Nursing, Egypt.

[18]. Ibrahim, S.A. (2002).The effect of a management training program for head nurses on the quality of nursing care rendered in Port Said general hospital (Unpublished Ph.D dissertation). Suez Canal University, Faculty of Nursing, Egypt.

[19]. Rodzik, B.E. (2008). Osteoprosis education in college-age women. Master Nursing (Thesis; Eastern Michigan University).

[20]. Wassef, A.K. (1998).The effect of leadership training program on the head nurses work performance (Unpublished doctorate thesis). Ain Shams University, High Institute of Nursing, Egypt.

[21]. Akel, D.T. (1997). The impact of an educational program on the head nurses performance as related to the planning function (Unpublished doctorate thesis). Ain Shams University, High Institute of Nursing, Egypt.

[22]. Mackenzie, J. \& Buchan, J. (1998). Ward management in practice. London. Churchill Livingstone, pp. 53-54.

[23]. Abd Rabo, A. (1997). Head nurses managerial skills: perceptions versus performance in selected university and private hospitals in Cairo (Unpublished master's thesis). Cairo University, High Institute of Nursing, Egypt.

TABLE "1": Distribution of the studied group according to their soci-demographic characteristics

\begin{tabular}{|c|c|c|}
\hline $\begin{array}{l}\text { Items } \\
\end{array}$ & No. & $\%$ \\
\hline 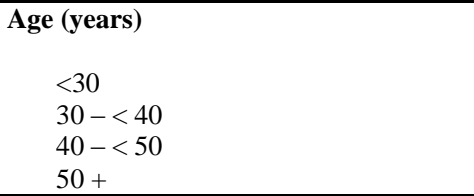 & $\begin{array}{c}11 \\
18 \\
13 \\
8\end{array}$ & $\begin{array}{l}22.0 \\
36.0 \\
26.0 \\
16.0\end{array}$ \\
\hline $\begin{array}{l}\text { Min. }- \text { Max. } \\
\text { Mean } \pm \text { SD. }\end{array}$ & \multicolumn{2}{|c|}{$\begin{array}{c}25.0-58.0 \\
39.12 \pm 10.15\end{array}$} \\
\hline $\begin{array}{l}\text { Nursing qualifications } \\
\text { Nursing diploma } \\
\text { Technical Health Institute } \\
\text { B.Sc.N. } \\
\end{array}$ & $\begin{array}{c}43 \\
4 \\
3 \\
\end{array}$ & $\begin{array}{l}86.0 \\
8.0 \\
6.0\end{array}$ \\
\hline $\begin{array}{l}\text { Nursing experience (years) } \\
\quad<5 \\
\quad \geq 5\end{array}$ & $\begin{array}{c}1 \\
49\end{array}$ & $\begin{array}{c}2.0 \\
98.0\end{array}$ \\
\hline $\begin{array}{l}\text { Min. }- \text { Max. } \\
\text { Mean } \pm \text { SD. }\end{array}$ & \multicolumn{2}{|c|}{$\begin{array}{c}3.0-37.0 \\
19.78 \pm 9.16\end{array}$} \\
\hline $\begin{array}{l}\text { Experience in maternity clinics(years) } \\
\quad<5 \\
\geq 5\end{array}$ & $\begin{array}{l}14 \\
36\end{array}$ & $\begin{array}{l}28.0 \\
72.0\end{array}$ \\
\hline $\begin{array}{l}\text { Min. }- \text { Max. } \\
\text { Mean } \pm \text { SD. }\end{array}$ & \multicolumn{2}{|c|}{$\begin{array}{l}1.0-30.0 \\
9.28 \pm 7.03\end{array}$} \\
\hline $\begin{array}{l}\text { Marital status } \\
\text { Married } \\
\text { Single } \\
\text { Widow } \\
\end{array}$ & $\begin{array}{c}44 \\
5 \\
1 \\
\end{array}$ & $\begin{array}{l}88.0 \\
10.0 \\
2.0\end{array}$ \\
\hline
\end{tabular}


TABLE-1 Distribution of the studied group according to their socio-demographic characteristics (cont.)

\begin{tabular}{|c|c|c|}
\hline Items & No. & $\%$ \\
\hline $\begin{array}{l}\text { Family income }(\mathbf{L E}) \\
\quad \leq 1000 \\
>1000 \\
\text { Min. }- \text { Max. } \\
\text { Mean } \pm \text { SD. }\end{array}$ & $\begin{array}{l}23 \\
27\end{array}$ & $\begin{array}{l}46.0 \\
54.0 \\
0 \\
23\end{array}$ \\
\hline $\begin{array}{l}\text { Source of information } \\
\text { No information } \\
\text { Health personal } \\
\text { Media }\end{array}$ & $\begin{array}{l}40 \\
7 \\
3\end{array}$ & $\begin{array}{c}80.0 \\
14.0 \\
6.0\end{array}$ \\
\hline $\begin{array}{l}\text { Do you suffer from polycystic ovary? } \\
\text { Yes } \\
\text { No }\end{array}$ & $\begin{array}{l}10 \\
40\end{array}$ & $\begin{array}{l}20.0 \\
80.0\end{array}$ \\
\hline $\begin{array}{l}\text { Family history } \\
\text { Yes } \\
\text { No }\end{array}$ & $\begin{array}{l}10 \\
40\end{array}$ & $\begin{array}{l}20.0 \\
80.0\end{array}$ \\
\hline $\begin{array}{l}\text { If yes "mention" the relation }(\mathbf{n}=\mathbf{1 0}) \\
\text { Sister } \\
\text { Relatives }\end{array}$ & $\begin{array}{l}5 \\
5 \\
\end{array}$ & $\begin{array}{l}50.0 \\
50.0\end{array}$ \\
\hline $\begin{array}{l}\text { How did you discover it? } \\
\text { Because of pain } \\
\text { Doctor examination } \\
\end{array}$ & $\begin{array}{c}2 \\
48 \\
\end{array}$ & $\begin{array}{r}4.0 \\
96.0 \\
\end{array}$ \\
\hline $\begin{array}{l}\text { Did you take training courses in PCOS? } \\
\text { Yes } \\
\text { No }\end{array}$ & $\begin{array}{c}2 \\
48 \\
\end{array}$ & $\begin{array}{r}4.0 \\
96.0 \\
\end{array}$ \\
\hline $\begin{array}{l}\text { Have you ever been involved in the management of thes } \\
\text { before? } \\
\text { Yes } \\
\text { No } \\
\end{array}$ & $\begin{array}{c}9 \\
41 \\
\end{array}$ & $\begin{array}{l}18.0 \\
82.0\end{array}$ \\
\hline $\begin{array}{l}\text { If yes : How many cases? }(\mathbf{n}=\mathbf{9}) \\
\text { Min. }- \text { Max. } \\
\text { Mean } \pm \text { SD. }\end{array}$ & & \\
\hline $\begin{array}{l}\text { Is the community in need for awareness about PCOS? } \\
\text { Yes } \\
\text { No }\end{array}$ & $\begin{array}{l}35 \\
15 \\
\end{array}$ & $\begin{array}{l}70.0 \\
30.0 \\
\end{array}$ \\
\hline
\end{tabular}

TABLE -2 Distribution of the studied group according to knowledge

\begin{tabular}{|c|c|c|c|c|}
\hline & \multicolumn{2}{|c|}{ Pre program } & \multicolumn{2}{|c|}{ Post program } \\
\hline & No. & $\%$ & No. & $\%$ \\
\hline \multicolumn{5}{|l|}{ Knowledge } \\
\hline Poor <50\% $(<30)$ & 49 & 98.0 & 10 & 20.0 \\
\hline Average $50-<65 \%(30-39)$ & 1 & 2.0 & 17 & 34.0 \\
\hline Good $\geq 65 \%(>39)$ & 0 & 0.0 & 23 & 46.0 \\
\hline \multicolumn{5}{|l|}{ Total score of knowledge } \\
\hline Min. - Max. & \multicolumn{2}{|c|}{$0.0-33.0$} & \multicolumn{2}{|c|}{$21.0-48.0$} \\
\hline Mean \pm SD & \multicolumn{2}{|c|}{$8.02 \pm 7.29$} & \multicolumn{2}{|c|}{$36.46 \pm 6.51$} \\
\hline \multicolumn{5}{|l|}{ \% score of knowledge } \\
\hline Min. - Max. & \multicolumn{2}{|c|}{$0.0-55.0$} & \multicolumn{2}{|c|}{$35.0-80.0$} \\
\hline Mean \pm SD & \multicolumn{2}{|c|}{$13.37 \pm 12.14$} & \multicolumn{2}{|c|}{$60.77 \pm 10.85$} \\
\hline $\mathbf{t}$ & \multicolumn{4}{|c|}{$19.174^{*}$} \\
\hline $\mathbf{p}$ & \multicolumn{4}{|c|}{$<0.001$} \\
\hline
\end{tabular}

t: Paired t-test for comparing between pre and post program

*: Statistically significant at $\mathrm{p} \leq 0.05$ 
TABLE -3 Area wise pre test-posttest knowledge scores of the studied group

\begin{tabular}{|c|c|c|c|c|c|c|}
\hline \multirow{2}{*}{ Knowledge Area } & \multicolumn{2}{|c|}{ Pre test knowledge score } & \multicolumn{2}{|c|}{ Posttest knowledge score } & \multirow[b]{2}{*}{$\mathbf{t}$} & \multirow[b]{2}{*}{$\mathbf{p}$} \\
\hline & Total score & Mean \pm SD \% & Total score & Mean \pm SD \% & & \\
\hline \multicolumn{7}{|c|}{$\begin{array}{l}\text { Anatomy of female reproductive system } \\
(\text { Max. score }=8)\end{array}$} \\
\hline Mean \pm SD. & $4.80 \pm 2.95$ & $60.0 \pm 36.86$ & $6.80 \pm 2.35$ & $85.0 \pm 29.34$ & $3.449^{*}$ & 0.001 \\
\hline \multicolumn{7}{|c|}{ Definition of PCOS (Max. score = 1) } \\
\hline Mean \pm SD. & $0.06 \pm 0.24$ & $6.0 \pm 23.99$ & $0.86 \pm 0.35$ & $86.0 \pm 35.05$ & $14.0^{*}$ & $<0.001$ \\
\hline \multicolumn{7}{|l|}{ Cause of PCOS (Max. score = 2) } \\
\hline Mean \pm SD & $0.30 \pm 0.74$ & $13.0 \pm 29.98$ & $1.60 \pm 0.57$ & $80.0 \pm 28.57$ & $10.111^{*}$ & $<0.001$ \\
\hline \multicolumn{7}{|l|}{ Risk factors (Max. score $=6$ ) } \\
\hline Mean \pm SD & $0.42 \pm 1.07$ & $7.0 \pm 17.85$ & $5.10 \pm 1.47$ & $85.0 \pm 24.57$ & $19.245^{*}$ & $<0.001$ \\
\hline \multicolumn{7}{|c|}{ Signs \& symptoms $($ Max. score $=6)$} \\
\hline Mean \pm SD & $0.36 \pm 0.92$ & $6.0 \pm 15.34$ & $4.26 \pm 1.75$ & $71.0 \pm 29.12$ & $13.499^{*}$ & $<0.001$ \\
\hline \multicolumn{7}{|l|}{ Complications (Max. score $=7$ ) } \\
\hline \begin{tabular}{|l} 
Mean \pm SD. \\
\end{tabular} & $0.24 \pm 0.69$ & $3.43 \pm 9.81$ & $4.62 \pm 2.25$ & $66.0 \pm 32.12$ & $13.400^{*}$ & $<0.001$ \\
\hline \multicolumn{7}{|l|}{ Diagnosis $($ Max. score $=3$ ) } \\
\hline Mean \pm SD & $0.40 \pm 0.78$ & $13.33 \pm 26.08$ & $2.60 \pm 0.67$ & $86.67 \pm 22.34$ & $14.819^{*}$ & $<0.001$ \\
\hline \multicolumn{7}{|c|}{ Objective of treatment $($ Max. score $=4)$} \\
\hline Mean \pm SD & $0.26 \pm 0.63$ & $6.50 \pm 15.82$ & $2.90 \pm 1.23$ & $72.50 \pm 30.83$ & $14.299^{*}$ & $<0.001$ \\
\hline \multicolumn{7}{|l|}{ Management (Max. score $=4)$} \\
\hline \begin{tabular}{|l} 
Mean \pm SD \\
\end{tabular} & $0.32 \pm 0.77$ & $8.0 \pm 19.19$ & $2.50 \pm 1.13$ & $62.50 \pm 28.23$ & $11.543^{*}$ & $<0.001$ \\
\hline \multicolumn{7}{|c|}{ Bad dietary habits $($ Max. score $=7)$} \\
\hline Mean \pm SD & $0.28 \pm 0.86$ & $4.0 \pm 12.26$ & $2.56 \pm 1.30$ & $36.57 \pm 18.52$ & $11.062^{*}$ & $<0.001$ \\
\hline \multicolumn{7}{|c|}{ Complementary therapy $($ Max. score $=1)$} \\
\hline Mean \pm SD. & $0.06 \pm 0.24$ & $6.0 \pm 23.99$ & $0.28 \pm 0.45$ & $28.0 \pm 45.36$ & $3.348^{*}$ & 0.002 \\
\hline \multicolumn{7}{|c|}{$\begin{array}{l}\text { Risk of un prescribed complementary } \\
\text { therapy (Max. score }=5 \text { ) }\end{array}$} \\
\hline Mean \pm SD & $0.06 \pm 0.31$ & $1.20 \pm 6.27$ & $0.20 \pm 0.57$ & $4.0 \pm 11.43$ & $2.189^{*}$ & 0.033 \\
\hline \multicolumn{7}{|l|}{ Exercise $($ Max. score $=1)$} \\
\hline \begin{tabular}{|l} 
Mean \pm SD \\
\end{tabular} & $0.16 \pm 0.37$ & $16.0 \pm 37.03$ & $0.66 \pm 0.48$ & $66.0 \pm 47.85$ & $6.093^{*}$ & $<0.001$ \\
\hline \multicolumn{7}{|l|}{ Nursing role $($ Max. score $=5$ ) } \\
\hline Mean \pm SD & $0.30 \pm 1.04$ & $6.0 \pm 20.70$ & $1.50 \pm 1.30$ & $30.0 \pm 25.95$ & $5.769^{*}$ & $<0.001$ \\
\hline
\end{tabular}

$\mathrm{t}$ : Paired t-test for comparing between pre and post program

*: Statistically significant at $\mathrm{p} \leq 0.05$ 
TABLE -4 Relation between knowledge post-test score and selected variables

\begin{tabular}{|c|c|c|c|c|c|c|c|c|}
\hline \multirow{3}{*}{ Items } & \multicolumn{6}{|c|}{ Knowledge } & \multirow{3}{*}{ Test of sig. } & \multirow{3}{*}{$\begin{array}{c}\mathbf{P} \\
\text { Value }\end{array}$} \\
\hline & \multicolumn{2}{|c|}{ Poor $(n=10)$} & \multicolumn{2}{|c|}{ Average (n=17) } & \multicolumn{2}{|c|}{$\operatorname{Good}(n=23)$} & & \\
\hline & No. & $\%$ & No. & $\%$ & No. & $\%$ & & \\
\hline Age (years) & & & & & & & & \\
\hline$<30$ & 1 & 10.0 & 4 & 23.5 & 6 & 26.1 & & \\
\hline $30-<40$ & 2 & 20.0 & 6 & 35.3 & 10 & 43.5 & $-2^{2}-4803$ & $M C_{n-0}-581$ \\
\hline $40-<50$ & 4 & 40.0 & 4 & 35.3 & 5 & 21.7 & $\chi^{2}=4.893$ & $p=0.581$ \\
\hline $50+$ & 3 & 30.0 & 3 & 17.6 & 2 & 8.7 & & \\
\hline $\begin{array}{l}\text { Min. - Max. } \\
\text { Mean } \pm \text { SD. }\end{array}$ & \multicolumn{2}{|c|}{$\begin{array}{c}27.0-57.0 \\
46.20 \pm 10.73 \\
\end{array}$} & \multicolumn{2}{|c|}{$\begin{array}{c}25.0-54.0 \\
38.47 \pm 9.47\end{array}$} & \multicolumn{2}{|c|}{$\begin{array}{c}25.0-58.0 \\
36.52 \pm 9.32\end{array}$} & $\mathrm{~F}=3.558^{*}$ & 0.036 \\
\hline $\begin{array}{l}\text { Nursing qualifications } \\
\text { Nursing diploma }\end{array}$ & 9 & 90.0 & 15 & 88.2 & 19 & 82.6 & & \\
\hline $\begin{array}{l}\text { Technical Health } \\
\text { Institute }\end{array}$ & 0 & 0.0 & 1 & 5.9 & 3 & 13.0 & $\chi^{2}=2.058$ & ${ }^{\mathrm{MC}} \mathrm{p}=0.795$ \\
\hline B.Sc.N. & 1 & 10.0 & 1 & 5.9 & 3 & 13.0 & & \\
\hline \multicolumn{9}{|l|}{$\begin{array}{l}\text { Nursing experience } \\
\text { (years) }\end{array}$} \\
\hline $\begin{array}{l}<5 \\
\geq 5\end{array}$ & $\begin{array}{l}1 \\
9\end{array}$ & $\begin{array}{l}10.0 \\
90.0\end{array}$ & $\begin{array}{c}0 \\
17\end{array}$ & $\begin{array}{c}0.0 \\
100.0\end{array}$ & $\begin{array}{c}0 \\
23\end{array}$ & $\begin{array}{c}0.0 \\
100.0\end{array}$ & $\chi^{2} \square=4.082$ & ${ }^{\mathrm{MC}} \mathrm{p}=0.207$ \\
\hline $\begin{array}{l}\text { Min. - Max. } \\
\text { Mean } \pm \text { SD. }\end{array}$ & \multicolumn{2}{|c|}{$\begin{array}{c}3.0-37.0 \\
25.70 \pm 11.21\end{array}$} & \multicolumn{2}{|c|}{$\begin{array}{c}7.0-35.0 \\
19.24 \pm 9.0\end{array}$} & \multicolumn{2}{|c|}{$\begin{array}{c}8.0-34.0 \\
17.61 \pm 7.46\end{array}$} & $\mathrm{~F}=2.987$ & 0.060 \\
\hline $\begin{array}{l}\text { Experience in maternity } \\
\text { clinics (years) }\end{array}$ & & & & & & & & \\
\hline $\begin{array}{l}<5 \\
\geq 5\end{array}$ & $\begin{array}{l}2 \\
8\end{array}$ & $\begin{array}{l}20.0 \\
80.0\end{array}$ & $\begin{array}{c}6 \\
11\end{array}$ & $\begin{array}{l}35.3 \\
64.7\end{array}$ & $\begin{array}{c}6 \\
17\end{array}$ & $\begin{array}{l}26.1 \\
73.9\end{array}$ & $\chi^{2}=0.808$ & ${ }^{\mathrm{MC}} \mathrm{p}=0.772$ \\
\hline $\begin{array}{l}\text { Min. - Max. } \\
\text { Mean } \pm \text { SD. }\end{array}$ & \multicolumn{2}{|c|}{$\begin{array}{c}1.0-3.0 \\
13.70 \pm 10.46\end{array}$} & \multicolumn{2}{|c|}{$\begin{array}{c}1.0-16.0 \\
7.12 \pm 4.54\end{array}$} & \multicolumn{2}{|c|}{$\begin{array}{c}1.0-22.0 \\
8.96 \pm 6.15\end{array}$} & $\mathrm{~F}=3.038$ & 0.057 \\
\hline \multicolumn{9}{|l|}{ Marital status } \\
\hline Married & 8 & 80.0 & 15 & 88.2 & 21 & 91.3 & $\chi^{2}=4.193$ & ${ }^{\mathrm{MC}} \mathrm{p}=0.556$ \\
\hline Single & 1 & 10.0 & 2 & 11.8 & 2 & 8.7 & & \\
\hline Widow & 1 & 10.0 & 0 & 0.0 & 0 & 0.0 & & \\
\hline \multicolumn{9}{|l|}{$\begin{array}{l}\text { Monthly family income } \\
\text { (LE) }\end{array}$} \\
\hline $\begin{array}{l}\leq 1000 \\
>1000\end{array}$ & $\begin{array}{l}4 \\
6\end{array}$ & $\begin{array}{l}40.0 \\
60.0\end{array}$ & $\begin{array}{c}7 \\
10\end{array}$ & $\begin{array}{l}41.2 \\
58.8\end{array}$ & 12 & $\begin{array}{l}52.2 \\
478\end{array}$ & $\chi^{2}=0.657$ & 0.720 \\
\hline $\begin{array}{l}\text { Min. - Max. } \\
\text { Mean } \pm \text { SD. }\end{array}$ & \multicolumn{2}{|c|}{$\begin{array}{c}800.0-2000.0 \\
1340.0 \pm 488.08\end{array}$} & \multicolumn{2}{|c|}{$\begin{array}{c}800.0-2000.0 \\
1265.59 \pm 425.34\end{array}$} & \multicolumn{2}{|c|}{$\begin{array}{c}800.0-2000.0 \\
1202.17 \pm 406.89\end{array}$} & $\mathrm{~F}=0.373$ & 0.691 \\
\hline \multicolumn{9}{|l|}{ Source of information } \\
\hline No information & 8 & 80.0 & 15 & 88.2 & 17 & 73.9 & & \\
\hline Health personal & 1 & 10.0 & 2 & 11.8 & 4 & 17.4 & $\chi^{2}=2.180$ & ${ }^{\mathrm{MC}} \mathrm{p}=0.767$ \\
\hline Others & 1 & 10.0 & 0 & 0.0 & 2 & 8.7 & & \\
\hline
\end{tabular}

$\mathrm{p}$ : $\mathrm{p}$ value for comparing between knowledge categories

$\chi^{2}$ : value for Chi square

MC: Monte Carlo test

F: F test (ANOVA)

$*$ : Statistically significant at $\mathrm{p} \leq 0.05$ 